\title{
EFFECTS OF PROTEIN AND VITAMIN B DEFICIENCY ON BLOOD PARAMETERS AND MYENTERIC NEURONS OF THE COLON OF RATS
}

\author{
Débora de Mello Gonçales Sant'Ana', Sônia Lucy Molinarr', Marcílio Hubner Miranda-Neto
}

\begin{abstract}
The aims of this work were to evaluate the effects of the deficient ingestion of protein and vitamin $B$ on the biochemical and hematologic parameters and on the NADH- and NADPH-diaphorase positive myenteric neurons. The control animals $(n=10)$ received commercial chow and the experimental rats $(n=10)$ received chow with protein level reduced to $8 \%$ during 120 days. At the time of killing blood was collected for assessment of the blood and hematologic parameters and the ascending colon for quantitative analysis of the neurons of the myenteric plexus. It was observed that the reduction of the protein level to $8 \%$ coupled to the reduction of the levels of vitamin $B$ in adult rats neither led to qualitative or quantitative changes on red or white blood cells, nor decreased globulin levels, induced the formation of edema or gave rise to clinical signs typical of protein or vitamin B deficiency. On the other hand, the experimental protocol led to less weight gain, change on the body composition with fat deposition; decrease of the values of serum total protein and albumin; reduction of the area of colon and density of nitrergic and NADH-diaphorase myenteric neurons inferior to the expected.
\end{abstract}

KEY WORDS: enteric neurons, proteic desnutrition, ascending colon, hematology, vitamin B.

\begin{abstract}
Efeitos da deficiência de proteínas e vitamina B sobre parâmetros sanguíneos e neurônios mioentéricos do colo de ratos adultos

RESUMO - Os objetivos deste trabalho foram avaliar as repercussões da ingestão deficiente de proteínas e vitaminas do complexo B sobre parâmetros bioquímicos e hematológicos e neurônios mientéricos NADH e NADPH-diaforase positivos. Os animais controle $(n=10)$ receberam ração comercial e os animais experimentais $(n=10)$ ração com teor protéico reduzido para $8 \%$ durante 120 dias. Durante o sacrifício, coletou-se o sangue dos animais para avaliação de parâmetros sanguíneos e hematológicos e o colo ascendente para a análise quantitativa dos neurônios do plexo mioentérico. Observou-se que a redução do teor de proteínas na dieta para $8 \%$ associado a redução no teor de vitaminas do complexo $\mathrm{B}$ em ratos adultos, não causa alterações qualitativas e quantitativas das células sanguíneas das séries vermelha e branca, não leva a redução do valor da globulina nem a formação de edema ou ao surgimento de sinais clínicos característicos das carências de proteínas e vitaminas do complexo B. Por outro lado causa: menor ganho de peso corporal; alteração da composição corporal com acúmulo de gordura; redução nos valores de proteína total e albumina; redução na área do colo e evidenciação de densidade de neurônios nitrérgicos e NADH-diaforase positivos inferior ao esperado.
\end{abstract}

PALAVRAS-CHAVE: neurônios entéricos, desnutrição protéica, colo ascendente, hematologia, vitamina B.

The utilization of animal models in studies of food restriction with known and controlled diets has as an advantage the improved knowledge about the many aspects of the human desnutrition ${ }^{1}$. Research on desnutrition aimsat simulating natural conditions, which involve deficiencies not only of protein (20$60 \%$ of the amount needed) but also of vitamins and minerals, with increased ingestion of carbohy- drates $^{2}$. The evaluation of these moderate forms of desnutrition is important because protein deficiency itself leads to a limitation of caloric expenditure with pathological changes that progress through several steps. The rate of evolution of these changes depends on the organic stores of the nutrients and on the adaptative metabolic changes aiming at making up for the deficiency ${ }^{3}$.

Program of Post-Graduation in Cell Biology, Doctorade, Universidade Estadual de Maringá (UEM) Maringá PR, Brazil: ${ }^{1}$ Professor of the Universidade Estadual de Maringa and Universidade Paranaense; ${ }^{2}$ Associate Professor of the Department of Morphophysiological Sciences / UEM; ${ }^{3}$ Titular Professor of DCM/UEM. This study was supported by CAPES, FADEC/UEM and IPEAC/UNIPAR.

Received 24 November 2000, received in final form 8 March 2001. Accepted 14 March 2001. 
Studies in children with Kwashiorkor demonstrated a decrease in the rate of synthesis of plasma albumin and absence of changes in the synthesis of gama-globulins ${ }^{4}$. In studies in rats it was demonstrated that when fed with a $0.5 \%$ protein diet, these animals had a decrease in the plasma levels of albumin and induction of edema ${ }^{1}$. Other authors also found a significant decrease in the albumin levels in rats subjected to desnutrition ${ }^{5,6}$. Experimental desnutrition is a fruitful area for the investigation of neuronal plasticity and the interdependence of neuronal and non-neuronal mechanisms ${ }^{7}$. Quantitative and morphological evaluations of the neurons of the myenteric plexus in malnourished rats have been demonstrating a larger neuronal density in the small intestine $^{8-11}$ and in the colon ${ }^{12}$, both due to the smaller growth of the animals and their bowels, which lead to lesser neuronal spreading. Most of the authors reviewed offered to the animals diets with protein deficiency but included minerals and vitamins of the complex $B^{8-12}$.

Because desnutrition is often multideficient, the association of protein deficiency with vitamin B deficiency being common, we carried out this work with the purpose of evaluating the results of the ingestion of a starch-rich, but protein- and vitamin B-deficient diet, on the biochemical and hematologic parameters and on the NADH- and NADPH-diaphorase positive myenteric neurons of rats.

\section{METHOD}

It was used 20 male Rattus norvegicus of the Wistar strain aging 90 days (298 $\pm 66 \mathrm{~g}$ body weight), which were kept and killed according to the rules of ethic conduct in animal experimentation ${ }^{13}$. The animals were divided in two groups, control and experimental. They were kept in individual cages with constant temperature and light-dark cycles of 12-12 hours. Water and chow were offered ad libitum. The control group received NUVILAB ${ }^{\circledR}$ [Recommended by the National Council of Research and National Institute of Health - USA] chow with protein level of $22 \%$ and the experimental group received a modified chow with protein level of $8 \%$, during 120 days.

The diet of the experimental group was obtained reducing the protein level of the NUVILAB ${ }^{\circledast}$ chow through the addition of corn starch and supplemented with a mixture of mineral salts, but without vitamin supplementation. This mode of preparation was based in models described in the literature ${ }^{9,12,14-17}$.

The weight gain of the animals was accompanied weekly, and from the $60^{\text {th }}$ to the $80^{\text {th }}$ day of the experiment they were kept in metabolic cages for daily evaluation of food and water ingestion and body weight.

During the whole experimental period the character- istics of the fur, paws, face and motor behaviour of the animals were observed comparing control and experimental rats.

At the $120^{\text {th }}$ day the animals were weighted and killed through excessive inhalation of ethylic ether. Next laparotomy was carried out and the colon was removed, which were measured in its length and width with a millimetered ruler.

The blood of 10 animals of each group was collected. Through the automatic enzymatic method with heparinized blood the dosage of plasma total protein and albumin was carried out and with the colorimetric method the concentration of globulins was assessed. Hemogram (eritrogram and leucogram) was made with the method of automatic cytometry by Scatter Laser and Electromagnetic. Hematocrit and hemoglobin concentration were also verified.

Retroperitoneal fat of five rats of each group was removed and weighted in analytical scales. The proportion of this fat relative to body weight was calculated.

The ascending colon of five animals of each group was filled with Krebs solution $(\mathrm{pH} 7.3)$, washed twice in the same solution (10 minutes each) and immersed for five minutes in $0.3 \%$ Triton $\mathrm{X}-100^{\circledR}$ solution dissolved in Krebs. They were washed twice more (10 minutes each) in Krebs solution and incubated for 45 minutes for the evidenciation of the NADH-diaphorase enzyme. This solution contained in each dl: $25 \mathrm{ml}$ of $0.5 \%$ stock solution of Nitro Blue Tetrazolium (NBT; Sigma, St. Louis, USA); $25 \mathrm{ml}$ of $0.1 \mathrm{M}$ phosphate buffer, $\mathrm{pH} 7.3 ; 50 \mathrm{ml}$ of distilled water and $50 \mathrm{mg}$ of $\beta$-NADH (Sigma, Steinheim, Germany), according to the technique of Gabella ${ }^{18}$. After incubation the segments were opened at the mesocolic margin and immersed in 10\% buffered formol solution.

The ascending colon of four animals of each group were washed and filled with phosphate buffer (PBS; pH 7.4), fixed in $4 \%$ paraformaldehyde (Merk, Darmstad, Germany) prepared in $0.1 \mathrm{M}$ phosphate buffer (PBS; $\mathrm{pH}$ 7.4) for 30 minutes, immersed in $0.3 \%$ Triton $X-100^{\circledast}$ (Sigma, St .Louis, USA) dissolved in saline phosphate buffer (PBS, pH 7.4) for 10 minutes and then washed ten times (10 minutes each) in PBS and immersed in the incubation medium for the neuronal evidenciation of the NADPH-diaphorase, during two hours ${ }^{19}$. This medium contained in each dl: $25 \mathrm{mg}$ of NBT; $50 \mathrm{mg}$ of $\beta$-NADPH (Sigma, Steinheim, Germany), $0.3 \%$ Triton $\mathrm{X}-100$ in $0.1 \mathrm{M}$ Tris- $\mathrm{HCl}$ buffer, pH 6.0 (GibcoBRL, N.Y. USA). After incubation, the segments were opened at the mesocolon insertion and washed three times in PBS for five minutes, and then immersed in $5 \%$ paraformaldehyde solution.

The whole-mounts were made under stereomicroscope with trans-illumination through removal of the tunica mucosa and the submucosa. Next they were dehydrated in ascending series of ethylic alcohol, diaphanized in xilene and mounted between slide and coverslip with Permount synthetic resin (Fischer Chemical, New Jersey, USA). 
Quantitative analysis was carried out on both techniques using Olympus BX40 microscope under 40X objective. In each whole-mount 80 microscopic fields were counted. Half-seen neurons were counted in alternate fields. The area of each microscopic field was $0.224 \mathrm{~mm}^{2}$.

It was calculated the mean, standard deviation and variation coefficient of all the data obtained. After realizing through the variation coefficient that the dispersion of the data was small, and thus that the mean was an excellent representative of the values, means were compared using Student's T test for non-paired data at the significance level of $5 \%$.

\section{RESULTS}

At the beginning of the experiment, the mean weight of the animals in the control group was $302.67 \pm 20.44 \mathrm{~g}$ and that of the rats in the experimental group was $296.09 \pm 34.96 \mathrm{~g}$. At the end of the experimental period the animals of the control group had a mean weight of $456.03 \pm 33.48 \mathrm{~g}$ and those of the experimental group $388.6 \pm 46.3 \mathrm{~g}$. The difference between the final weights was statistically significant $(t=2.74 ; c . v .=1.67 ; p<0.05)$.

In the control animals it was found a mean of $7.43 \pm 0.82 \mathrm{~g}$ of retroperitoneal fat, which corresponded to $1.85 \pm 0.23 \mathrm{~g} / 100 \mathrm{~g}$ body weight. In the ex- perimental animals a mean of $8.7 \pm 0.74 \mathrm{~g}$ was found $(\mathrm{t}=2.74$; $\mathrm{c} . \mathrm{v} .=1.67)$, corresponding to $2.88 \pm 0.31 \mathrm{~g} /$ $100 \mathrm{~g}$ body weight $(t=6.06 ;$ c.v. $=1.67)$.

Through the biochemical dosages of the blood of the control and experimental animals it was verified that there was a decrease in the mean value of total protein and serum albumin, as observed in Table 1 ; however, there were no significant changes in the values of hematocrit and hemoglobin, as well as in the counting of erythrocytes and leucocytes, as can be seen in Table 2 .

During the whole experimental period the disnurtured rats showed the extremities of the limbs, fur and motor behaviour similar to those of the controls. During laparotomy, an increase of peritoneal fluid was not observed. In the experimental animals a visibly shorter and thinner colon was noted, being surrounded by adipose tissue as well.

In Table 3 it is observed the differences in the length, width and area of the colon of both groups.

The NADPH-diaphorase positive neurons of the experimental animals showed a density $3.7 \%$ greater than that of the control animals, while for the NADHdiaphorase positive neurons this difference reached $27 \%$ (Table 4).

Table 1. Mean blood values of total protein and fractions $(\mathrm{g} / 100 \mathrm{ml})$ in the plasma of Wistar rats aging seven months from the control and experimental groups. Mean \pm standard deviation.

\begin{tabular}{lccc}
\hline Group & $\begin{array}{c}\text { Total Protein* } \\
(\mathrm{g} / \mathrm{dL})\end{array}$ & $\begin{array}{c}\text { Albumin } \\
(\mathrm{g} / \mathrm{dL})\end{array}$ & $\begin{array}{c}\text { Globulin } \\
(\mathrm{g} / \mathrm{dL})\end{array}$ \\
\hline Control $(\mathrm{n}=5)$ & $6.52 \pm 0, .4 \mathrm{a}$ & $3.97 \pm 0.53 \mathrm{a}$ & $2.6 \pm 0.49 \mathrm{a}$ \\
Malnourished $(\mathrm{n}=5)$ & $5.94 \pm 0.32 \mathrm{~b}$ & $3.22 \pm 0.58 \mathrm{~b}$ & $2.72 \pm 0.31 \mathrm{a}$ \\
Reference value $^{* *}$ & $6.3-8.6$ & $3.3-4.9$ & $2.4-3.9$ \\
\hline
\end{tabular}

*Dosages carried out with the Automatic Enzymatic Method. ** Source:21

Means followed by the same letter for each variable do not differ at the significance level of $5 \%$.

Total Protein ( $t=2.9$; c.v. 1.86 ); Albumin ( $t=2.25$; c.v. 1.86); Globulin ( $t=0.47$; c.v. 1.86)

Table 2. Mean values of hemoglobin $(\mathrm{g} / 100 \mathrm{ml})$, hematocrit $(\%)$, number of erythrocytes and leucocytes (million/ $\left.\mathrm{mm}^{3}\right)$ of adult Wistar Rattus norvegicus of the control and experimental groups. Mean \pm standard deviation.

\begin{tabular}{lcccc}
\hline Group & Hematocrit $(\%)$ & Hemoglobin* $(\mathrm{g} / \mathrm{dL})$ & $\begin{array}{c}\text { Erytrocyte } \\
\text { Million/mm3 }\end{array}$ & $\begin{array}{c}\text { Leucocytes }^{1} \\
\text { Million/mm }\end{array}$ \\
\hline Control $(\mathrm{n}=5)$ & $47.2 \pm 2.6 \mathrm{a}$ & $15.58 \pm 0.876 \mathrm{a}$ & $8.06 \pm 0.78 \mathrm{a}$ & $5.4 \pm 1.69 \mathrm{a}$ \\
Malnourished $(\mathrm{n}=8)$ & $46.0 \pm 2.4 \mathrm{a}$ & $15.11 \pm 0.11 \mathrm{a}$ & $8.27 \pm 0.36 \mathrm{a}$ & $5.8 \pm 2.2 \mathrm{a}$ \\
Reference value $^{* *}$ & $41-52$ & $11.5-16.0$ & $5.4-8.5$ & $4.0-10.2$ \\
\hline
\end{tabular}

* Dosages carried out with Automatic Cytometry Method by Scatter Laser and Electromagnetic. **Source:21

Means followed by the same letter for each variable do not differ at the significance level of $5 \%$.

Hemoglobin ( $t=1.46$; c.v. 1.782); Hematocrit $(t=0,85$; c.v. 1.782); Erytrocytes $(t=0.69$; c.v. 1.782); Leucocytes ( $t=0.398$; c.v. 1.782). 
Table 3. Mean lengths and widths of the total colon of adult rats from the control and experimental groups. Area of total colon based on the measures of length and width.

\begin{tabular}{|c|c|c|c|}
\hline Group & $\begin{array}{l}\text { Lengths of total } \\
\text { colon }(\mathrm{cm})\end{array}$ & $\begin{array}{l}\text { Widths of total } \\
\text { colon }(\mathrm{cm})\end{array}$ & $\begin{array}{c}\text { Area of total } \\
\text { colon }\left(\mathrm{cm}^{2}\right) \\
\text { (lengths } \mathrm{x} \text { widths) }\end{array}$ \\
\hline Control $(n=7)$ & $18.34 \pm 1.0 \mathrm{a}$ & $1.66 \pm 0.21 \mathrm{a}$ & $30.1 \pm 4.35 \mathrm{a}$ \\
\hline Malnourished $(n=7)$ & $13.6 \pm 0.8 b$ & $1.04 \pm 0.13 b$ & $13.78 \pm 2.46 b$ \\
\hline
\end{tabular}

Means followed by the same letter for each variable do not differ at the significance level of $5 \%$ Lengths ( $t=11.0 ;$ c.v. 1.77); Widths ( $t=6.7$; c.v. 1.77$)$; Area $(t=8.72 ; c . v .=1.77)$

Table 4. Incidence of neurons in the myenteric plexus of the ascending colon of adult rats from the control and experimental groups evidenced by the techniques of NADPH-diaphorase and $\mathrm{NADH}$-diaphorase in 80 microscopic fields (area of $17.92 \mathrm{~mm}^{2}$ ). Mean \pm standard deviation.

\begin{tabular}{lcc}
\hline Group & NADPH-d $(n=4)$ & NADH-d $(n-=5)$ \\
\hline Control & $1609 \pm 115.6$ a & $1464.8 \pm 209.2$ a \\
Malnourished & $1671 \pm 729.4$ a & $2006.4 \pm 489.1$ b \\
\hline
\end{tabular}

Means followed by the same letter in the same column do not differ statistically at the significance level of $5 \%$. NADPH-d $(t=0.16$; c.v. 1.946); $\mathrm{NADH}(\mathrm{t}=2.29 ; \mathrm{c} . \mathrm{v} .=1.86)$

Means followed by the same symbol ( $\$$ )in each row do not differ statistically at the significance level of $5 \%$. Control $(t=1.23$; c.v. $=$ 1.89); Malnourished ( $t=0.83$; c.v. $=1.89$ ).

\section{DISCUSSION}

The addition of starch with resultant decrease of the protein and vitamin levels did not induce qualitative and quantitative changes in the red blood cells, which was showed through the counting of the erythrocytes, the hematocrit and the dosage of hemoglobin. Previously it was verified that the deficiency of vitamins from the complex $B$, which in humans lead to megaloblastic anemia, does not do it in rats ${ }^{20}$.

In this experiment, the value found for the total plasma proteins of the experimental animals $(5.94 \pm 0.32 \mathrm{~g} / \mathrm{dl})$ was lower than the minumum reference value for rats $\left(6.3-8.6 \mathrm{~g} / \mathrm{dl}^{21}\right)$ but similar to that found in rats receiving diet with equivalent protein level but with vitamin B supplementation (5.88 \pm 0.31 $\left.\mathrm{g} / \mathrm{dl}^{17}\right)$. Decreases in the values of total protein were also found in rats fed with protein-free diet ${ }^{5,6}$ and with diets containing 0 and $4 \%$ protein levels ${ }^{22}$.

The mean value of serum albumin $(3.22 \pm 0.58 \mathrm{~g} /$ dl) was slightly inferior to the reference value (3.3$4.9 \mathrm{~g} / \mathrm{dl}^{21}$ ), this possibly prevented an apparent interference with the hemodynamic conditions of the animals. Significant reductions of serum albumin in rats in the absence of edema were also found with protein-free diet during 28-32 days $s^{5}$ and during 84 days ${ }^{6}$.

The formation of edema associated to a significant decrease of albumin was found with proteinfree diet $^{22}$ through a $50 \%$ decrease in the amount of ration offered to the animals during gestation and the first six weeks after birth ${ }^{23}$. Many authors stress that the rats are not suited to reproduce this characteristic of Kwarshiorkor, because they seldom develop nutritional edema ${ }^{14}$.

As for the diet offered by Firmansyah et al. ${ }^{23}$ it is implicit that the animals had their protein ingestion reduced to a half, while in the present experiment the decrease in the protein level of the diet was of $63 \%$; despite this, the rats did not loose weight nor suffered a marked decrease in their albumin levels, possibly because proteins were spared and the major energy source was the oxidation of carbohydrates, which were added to the diet so as to keep caloric offer, while the experimental animals of Firmansyah et al. ${ }^{23}$, being in a critical period of growth, used protein both structurally and as an energy source due to the lower carbohydrate ingestion, resulting in a reduced protein availability reflected in the tissue and circulating albumin levels.

Although total protein was reduced, the value for globulin $(2.52 \pm 0.19 \mathrm{~g} / \mathrm{dl})$ was within the reference range for this species $\left(2.4-3.9 \mathrm{~g} / \mathrm{dl}^{21}\right)$. Normal values for globulin were also found in rats subjected to proteic deficiency $\left(2.72 \pm 0.31 \mathrm{~g} / \mathrm{dl}^{17}\right)$.

The normality in the values for globulin and the absence of changes in the counting of white blood cells indicate that the imposed nutritional deficiency did not lead to immune depression; this observation is supported by the fact that the animals had no clinical signs of illness during the whole experimental period.

The importance of proteins in the processes of synthesis of substances for growth and tissue re- 
newal was demonstrated by the lower weight gain and smaller bowels of the experimental animals, similar to the findings in rats with protein desnutrition ${ }^{16}$.

The calories from carbohydrates, both in rats and in humans, although fundamental for energy, are nule from the point of view of the processes of synthesis of plastic substances ${ }^{24,17}$.

The weight gain verified during the experimental period was due primarily to fat deposition. This would be produced from the excess carbohydrate, because albeit these animals had smaller body weights the amount and proportion of retroperitoneal fat relative to the body weight were larger than in the controls. Thus, an implication of this diet is an alteration of the body composition with increased fat relative to lean mass.

When comparing the density of NADPH-diaphorase positive neurons between the groups, statistically significant differences were not found, yet, as the colon area of the experimental animals represented $45.8 \%$ of that of the controls, it was expected that the neuronal density were $54.2 \%$ greater, because the smaller the intestinal area, the lesser the neuronal spread. However, the density of these neurons was only $3.7 \%$ greater than that of the control animals. Therefore, about $50.5 \%$ of the nitrergic neurons and $27.2 \%$ of the NADH-diaphorase positive neurons of the ascending colon were not evidenced. Significant reductions in the number of myenteric neurons of malnourished rats were also verified in other investigations, and have been attributed to the nutritional deficiency to which the animals were subjected $^{8-11,16}$.

However, we cannot state that all the nitrergic neurons which were not seen have been lost, once their evidenciation by the NADPH-diaphorase technique is made possible due to the formation of formazan granules from nitro blue tetrazolium, which functions as an artificial electron acceptor. In the specific case of the nitrergic neurons the production of nitric oxide from L-arginine depends on the energy supplied by the oxidation of NADPH, as catalized by the enzyme NADPH-diaphorase.

As the vitamins of the complex B participate of the pathways of carbohydrate utilization and niacine of the synthesis and composition of the adenine nucleotides, and as its ingestion was about $20 \%$ smaller than recommended ${ }^{25}$ and $75 \%$ smaller than the amount ingested by the control animals, the hypotesis can be put forward that in the neurons of the myenteric plexus a deficiency of these elements is taking place, with resultant reduction in the energy available to drive the formation of nitric oxide from L-arginine.

Despite niacine being possibly the major substrate of the electron-carrier substances $\left(\mathrm{NAD}^{+} / \mathrm{NADH}\right.$; $\left.\mathrm{NADP}^{+} / \mathrm{NADPH}\right)^{26}$, we believe that a possible deficiency of L-arginine could be added as an explanation for the lesser evidenciation of the NADPH-diaphorase positive neurons, because its decreased availability for the synthesis of nitric oxide would impair the evidenciation of the NADPH-diaphorase positive neurons. On the other hand, lipogenesis, which depends on NADPH when taking place through the pentose-ribose phosphate pathway or on NADH and NADPH when through the glycolitic pathway, was mantained, as evidenced by the increased retroperitoneal fat.

In these animals we observed reduced serum albumin, which can be related to the reduced availability of essential aminoacids. In pigs with limited protein ingestion it was verified an alteration in the ratio of non-essential/essential aminoacids from the fall of plasma albumin onwards ${ }^{27}$. Also in malnourished children it was found a decreased plasma concentration of essential and some non-essential aminoacids, among which L-arginine ${ }^{28}$. It should be stressed that arginine is considered an essential aminoacid in growing and young rats ${ }^{26}$, but not in adult animals. In humans with protein desnutrition arginine is reduced because it participates of protein synthesis and is used in the urea cycle as well ${ }^{29}$.

Another evidence of the importance of the reduced protein intake for the decreased evidenciation of the nitrergic neurons is the fact that the NADHdiaphorase positive neurons suffered a less marked reduction, although their evidenciation also depends upon an adenine nucleotide as energy substrate. It should also be considered that even the components of the vitamin B complex having been reduced due to the addition of starch, they were present in amounts sufficient to prevent clinical manifestations such as cutaneous, muscular, neurologic and hematologic changes, which are common in instances of marked deficit of vitamins from the complex B, although the animals could be in a pre-clinical step. In humans, for each case of extreme desnutrition there are 15-20 cases of pre-clinical alterations ${ }^{3}$. In this period the energy stores decrease and biochemical changes begin to appear, and the functional and anatomical changes arise in the clinical period ${ }^{3}$.

In summary, this experiment demonstrated that the decrease of the protein level of the diet to $8 \%$ 
coupled to a decrease in the level of vitamins from the complex B in adult rats does not lead to qualitative or quantitative changes of the blood cells both of the red and the white series, does not reduce the levels of globulin nor lead to edema or the appearance of clinical signs characteristic of protein and vitamin B deficits. On the other hand it causes: less weight gain; change in the body composition with increased fat deposition; decrease in the values of total protein and albumin; decrease in the colonic area, and evidenciation of nitrergic and NADH-diaphorase positive neurons at densities inferior to those expected.

Aknowledgements - We thank Prof. Msc. Cecília Edna Mareze da Costa, from the area of Physiology of the Department of Morphophysiological Sciences of the Universidade Estadual de Maringá for the help with the technique of isolation of the retroperitoneal fat and with the sacrifice of the animals.

\section{REFERENCES}

1. Enwonwu CO, Sreebny LM. Experimental protein-calorie malnutrition in rats. Biochemical and ultrastructural studies. Exp Molec Patol 1970;12:332-353.

2. Waterlow JC. Malnutrición proteico-energética. Washington: OPS 1996. $550 \mathrm{p}$.

3. Nóbrega FJ. Distúrbios da nutrição. Rio de Janeiro: Revinter 1996:4594;188-278.

4. Cohen S, Hansen JDL. Metabolism of albumin and g-globulin in Kwashiorkor. Proceedin of the nutrition society of South Africa 1962;3:26-31

5. Campana AO, Burini CR, Outa AY, Camargo JLV. Experimental protein deficiency in adult rats. Rev Bras Pesqui Méd Biol 1975;8:221-226.

6. Maffei HVL, Rodrigues MAM, Camargo JLV, Campana AO. Intraephithelial ly,phocytes in jejunal mucosa of malnourished rats. Gut 1980;21:32-36.

7. Furness JB, Costa M. The enteric nervous system. Edimburg: Churchill Livingstone, 1987.

8. Torrejais MM, Natali MRM, Conegero CI, Miranda-Neto MH. Effect of protein malnutrition after breast-feeding on the morphology of the intestinal wall and myenteric neurons of the ileum rats. Rev Unimar 1995;17:315-327.

9. Natali MRM, Miranda-Neto MH. Effect of maternal proteic undernutrityion on the proteic undernutrition on the neuron of the myenteric plexus of the duodenum of rats. Arq Neuropsiquiatr 1996;54:273-279.

10. Brandão MCS. Análise morfoquantitativa do plexo mientérico do intestino delgado de ratos jovens submetidos à denutrição protéica pré e pós-natal: Dissertação de Mestrado, Instituto de Ciências Biomédicas, Universidade de São Paulo. São Paulo, 1998.

11. Meilus M, Natali MRM, Miranda-Neto MH. Study of the myenteric plexus of the ileum of rats subjected to protein undernutrition. Rev Chil Anat 1998;16:9-14.

12. Sant'Ana DMG, Miranda-Neto MH, Molinari SL, Sant'Ana MA. Neuron number of the ascending colon of plexus of the ascending colon of rats a comparative study using two staining thecniques. Arq Neuropsiquiatr 1997;55:460-466.

13. BRASIL, Lei n. $6.638,8$ de Maio de 1979. Normas para a prática didático científica da vivissecção de animais e determinação de outras providências. Lex 1979;43:416.

14. Moura AS. Estudo em ratos do processo de adaptação à dietas com níveis variados de proteínas com e sem restrição energética. Tese de Doutorado, Instituto de Ciências Biomédicas, Universidade de São Paulo. São Paulo, 1994

15. Lepri ER, Bruschii LC, Moura AS. Efeitos da desnutrição protéica durante os períodos pré e pós natal no desenvolvimento cerebelar. Rev Bras Cienc Morfol 1994;11:22-27.

16. Sant'Ana DMG, Miranda-Neto MH, Souza RR, Molinari SL. Morphological and quantitative study of the myenteric plexus of the ascending colon of rats subjected to proteic desnutrition. Arq Neuropsiquiatr 1997;55:687-695

17. Natali MRM. Estudo morfoquantitativo e ultra-estrutural do plexo mientérico do duodeno de ratos (Rattus norvegicus) adultos submetidos a carência protéica. Tese de Doutorado, Instituto de Ciências Biomédicas, Universidade Estadual Paulista. Botucatu, 1999.

18. Gabella G. Dettection of nerve cells by histochemical technique. Experientia 1969;25:218-219.

19. Scherer-Singler U, Vincent CR, Kimura H, Mc-Geer EG. Demonstration of a unique population of neurons with NADPH-diaphorase histochemistry. J Neurosci Methods 1983;9:229-234.

20. Woodart JC, Newberne PM. Relation of vitamin B12 and 1-carbon metabolism to hydrocephalus in the rat. J Nutr 1966;88:375-381.

21. Hillyer EV, Quesenberry KE. Ferrets, rabbits and rodents clinical medicine and surgery. London: Saunders, 1997.

22. Amorim CSC. Estudo morfológico da mucosa intestinal de ratos submetidos a desnutrição protéico-calórica experimental. Tese de Doutorado, Faculdade de Medicina de Ribeirão Preto, Universidade de São Paulo. Ribeirão Preto, 1984.

23. Firmansyah A, Suwandito L, Penn D, Lebenthal E. Biochemical and morphological changes in the digestive tract of rats after prenatal and postnatal malnutrition. Am. J Clin Nutr 1989;50:261-268.

24. Marcondes E. Pediatria Básica. São Paulo: Sarvier, 1978.

25. National Research Council. Nutrient requirements of laboratory animals. 4.Ed. Washington, D.C.: National Academic Press, 1995:11-79.

26. Linder MC. Nutritional biochemistry and metabolism. 2.Ed. Norwalk: Appleton \& Lange, 1991.

27. Widdowson EM. The place of experimental animals in the study of human nutrition. In Mc Cance RA, Widdowson EW (eds). Calorie deficiences and protein deficiencies. London: Churchill, 1966:225-236.

28. Arroyale G, Wilson D, Funes C, Beham M. The free aminoacids in blood plasma of children with kwashiorkor and marasmus. Am J Clin Nutr 1968;11:517-524.

29. Holt LE, Snyderman SE, Nortgon PM, Roitman E, Finch J. The plasma aminogram in kwashiorkor. Lancet 1963;2:1343-1348. 